\title{
Who Is For or Against the Park? Factors Influencing the Public's Perception of a Regional Park: A Slovenian Case Study
}

\author{
Mojca Nastran' and Majda Černič Istenič \\ University of Ljubljana, Slovenia
}

\section{Abstract}

To effectively organize cooperation with stakeholders in the planning and management of protected areas, it is important to understand their perception of the protected area and the factors influencing that perception. This study identifies the factors and their impact on locals' perceptions of the KamniškoSavinjske Alps Regional Park in designation, Slovenia. The results of discriminant analysis show that the local population that supports the park has significantly different views of its potential from the population that opposes it. In addition, the local population that supports the park was personally notified by the founders about the plans, while the opposing population was not. Therefore, the former is more trustful of the founders' procedures and there is more cooperation with all interest groups than with the opposing population. Contrary to our expectations, higher education, place of residence, and gender do not affect the population's support for the park. These results confirm that a consideration of the factors that affect the local population's perception of the protected area contributes to more effective involvement of stakeholders in the process of park creation, which is important for the successful management of protected areas.

Keywords: attitude, local stakeholders, park-people relationship, park in designation, perceptions, protected areas

\section{Introduction}

During the past decade increased emphasis has been given to the role of different stakeholders in the process of founding and operating protected areas (PAs). Among the most important stakeholders are the local populations (Nastran, 2013). The outcome of PA founding and operating depends significantly on

1 Corresponding author: mojca.nastran@bf.uni-lj.si. 
these stakeholders' perceptions and involvement. However, countries that have to implement national and international nature protection goals set up PAs quickly and without thinking the process through fully, and they tend to neglect the importance of local community involvement (e.g., Alonso-Yañez \& Davidsen, 2014). Several cases of PA founding in Slovenia have been halted in recent years. For example, establishment of the Snežnik Regional Park, after a promising informal start, came to a standstill during the formal phase of the founding process, mostly due to opposition from local stakeholders (Nastran \& Pirnat, 2012). Local opposition has also resulted in the failure to open Karst Regional Park (Fakin Bajec, 2009) and Kočevje Regional Park (Erhatič Širnik, 2003). The common problems in these situations were mostly due to a topdown approach to the establishment of the PA, a lack of direct participation of local inhabitants, a lack of clear support from the local authority, and the opposition of local industry. There has been, however, some positive experience with local stakeholders' perceptions of PAs, and this is mostly the result of the stakeholders being involved in the park founding process. The initiative to found the Goričko Nature Park came from the local population, using the bottom-up principle (Grošelj, 2008; Rodela, 2010). When the Ljubljana Marsh Nature Park was being planned, great emphasis was placed on including different stakeholders and using their local knowledge and information. It seems this type of practice contributes greatly to the local population's positive perception of PAs, as demonstrated by cases in other parts of the world (Conrad \& Hilchey, 2011; Toomey \& Domroese, 2013). Due to negative experiences in the past, special attention is now given to informing and striving for cooperation with stakeholders. Currently, several PAs are in designation in Slovenia and their founding is not being carried out hastily. Parks in designation are planned but not yet formally established through government regulations. At the beginning of the establishment process an agreement is signed among the actors (founders can be government; local authority, i.e., municipality; or the government along with a municipality). Well-thought-through cooperation with stakeholders and the bottom-up principle are being applied. As the idea of a PA takes time to mature, the in-between stage of the park "in designation" has frequently proven itself to be the appropriate time to include local stakeholders in the planning of the park and its contents (Mikuš, 2006). A new regime should be introduced gradually, its consequences monitored, and findings fed back to further refine the process of development.

Based on this short overview of different results pertaining to the establishment of PAs in Slovenia, indicating the profound importance of the stakeholders' opinions, the aim of this article is to determine the factors and their extent in influencing the local population's perception toward the PA. For this purpose, the Kamniško-Savinjske Alps Regional Park (KSARP) in designation, Slovenia, 
is used as a case study that follows and intends to contribute to the already existing discussion about the nature of population attitudes toward PAs in various parts of the world.

\section{Research background}

Research shows that the stakeholder's perception of the PAs provides important information (Arnberger et al., 2012; Swim et al., 2014) when it is communicated to the planners and the refined proposal is represented to the stakeholder in a process of ongoing collaborative participation regarding methods and time of inclusion in the PA designation and management process (Flints, 2010; Hu et al., 2010; Kos, 2002). In this way, in later stages such as planning the service of the park, managers are already acquainted with the interests and needs of the locals; this knowledge enables them to more easily convince the locals to participate in the activities the park has to offer. This is in line with procedural justice theory (Lind \& Tyler, 1988), where the ability to participate, to be heard, and to be treated with respect is even more important than the outcomes of the process.

There is no general consensus in the literature regarding what influences the local population's perception of a PA (Triguero-Mas et al., 2009). The most frequently mentioned are socioeconomic influences such as age (Karanth \& Nepal, 2012; Shibia, 2010; Tomicevic et al., 2010), gender (Allendorf \& Allendorf, 2013; Karanth \& Nepal, 2012), education (Shibia, 2010; Tomicevic et al., 2010; Triguero-Mas et al., 2009), wealth and land size (Allendorf, 2010; Karanth \& Nepal, 2012; Kideghesho et al., 2007), group membership (e.g., farmers, entrepreneurs) (Arnberger \& Schoissengeier, 2012; Bonaiuto et al., 2002; Kideghesho et al., 2007; Shibia, 2010), ethnicity (Mehta \& Heinen, 2001), and place of residence (Bonaiuto et al., 2002; Triguero-Mas et al., 2009; Vodouhê et al., 2010). Positive perception of the PA is most strongly associated with higher education, higher income, and living outside the park boundaries. For gender and age the literature provides no uniform view on their importance in terms of PA support. The impact of group membership on perception mostly appears because of different interests and activities of individual groups. Other factors that have been measured several times include participation (Arnberger \& Schoissengeier, 2012; Hirschnitz-Garbers \& Stoll-Kleemann, 2011; Macura et al., 2011; Niedziałkowski et al., 2012; Sirivongs \& Tsuchiya, 2012; Toomey \& Domroese, 2013), perceived benefits and costs of the PA (Ezebilo \& Mattsson, 2010; Hirschnitz-Garbers \& Stoll-Kleemann, 2011; Karanth \& Nepal, 2012; Macura et al., 2011; Niedziałkowski et al., 2014; Shibia, 2010; Sirivongs \& Tsuchiya, 2012; Stringer \& Paavola, 2013; Vodouhê et al., 2010), perception of the park management or manager (Allendorf et al., 2007; Macura et al., 2011; Vodouhê et al., 2010), trust in managers (Abbas et al., 2014; Macura et 
al., 2011), local population's attitude toward nature conservation (Arnberger \& Schoissengeier, 2012; Tomicevic et al., 2010), and the degree to which the local population is informed about the PA and their knowledge about the PA (Htun et al., 2012; Macura et al., 2011; Niedziałkowski et al., 2012). These factors have very different effects on perception. In the abovementioned studies, they are found to have a significant impact on the perception of a PA, and this impact is not always positive. Some qualitative studies show the importance of more psychological factors such as regional identity, place attachment (Bonaiuto et al., 2002), and psychological reactance (Arnberger \& Schoissengeier, 2012); these frequently coincide with the previously mentioned factors. It seems that these factors are more significant (or better researched) in developed countries. In developing countries, other factors, such as income and obtaining vital goods from a park area (perceived benefits and costs or wealth), have a greater influence on local populations' perceptions of PAs.

In contrast to the studies reported above that consider parks which have operated for years, this study is special because KSARP is still in the designation process. Since stakeholders' perceptions can change quickly based on the way the PA is being founded, the study results presented here can be seen as an example when stakeholder involvement in further phases of the park's establishment is planned. With knowledge of the perceptions and factors influencing the stakeholders' attitudes in the initial stage of PA formation, this study can offer recommendations for considering stakeholder involvement in the successful establishment and management of PAs.

\section{Study area}

Extensive PAs are to expand and cover one third of Slovenia's surface in order to preserve biodiversity (Government of Republica Slovenia, 2006). Extensive PAs are not only connected with conservation but with development goals as well. Successful cooperation with local stakeholders can be an important guideline in founding a PA and achieving its goals. Slovenian parks are divided into three categories: national (IUCN category II), regional (IUCN II, V), and landscape park (IUCN V). Permitted or prohibited activities, such as driving, camping, or lighting fires, are specified for each park in its Act. Regional parks can be divided into several conservation zones. A strict conservation zone is primarily intended for preservation of natural values, primeval nature, favorable status of protected species and their habitats, and natural development of ecosystems. Agricultural and forestry use, if consistent with the conservation objectives, is admissible. The less strict conservation zone, in addition to nature protection, also encourages the hitherto use of natural resources through the implementation of agriculture and forestry and, with the protection objectives, tourist and 
recreational activities. This type of zone is designed to maintain the diversity of the landscape. Settlements with tourist facilities and local crafts are usually located in this zone. In landscape parks (natural parks), in addition to the protection of nature, strong emphasis is placed on protecting the landscapes, which has benefits from an ecological, biological, and landscape-oriented point of view. They were created along with high-quality and long-term interaction between man and nature.

The KSARP has officially been in the designation process since 2005 when the founders, the Ministry of Agriculture and the Environment and five municipalities in the area of the planned park (Jezersko, Preddvor, Kamnik, Luče, and Solčava), signed an agreement on the founding of the park. The park designation has been at a standstill since 2010. Since then, expert reports have been compiled, the population has been notified about the park designation and its contents, communication with some large landowners in the park has taken place, and draft regulation on its founding has been discussed. The park's founders are responsible for the establishment process, while the manager of the established park will be defined later.

The planned regional park encompasses the Kamniško-Savinjske Alps (KSA) mountain range and its valley edges, where a majority of the park area population is concentrated. KSA is an extensive mountain range connected to the Southern Limestone Alps. Together with the Karavanken Mountains, it forms the mountain range between Slovenia and Austria (Figure 1). In the past, people cleared the forests and lowered the tree line to form a cultural landscape, but forest still cover two thirds of the surface of the proposed park area. The main economic sectors in the area are forestry, animal husbandry, and recently developed tourism (Nastran, 2015). 


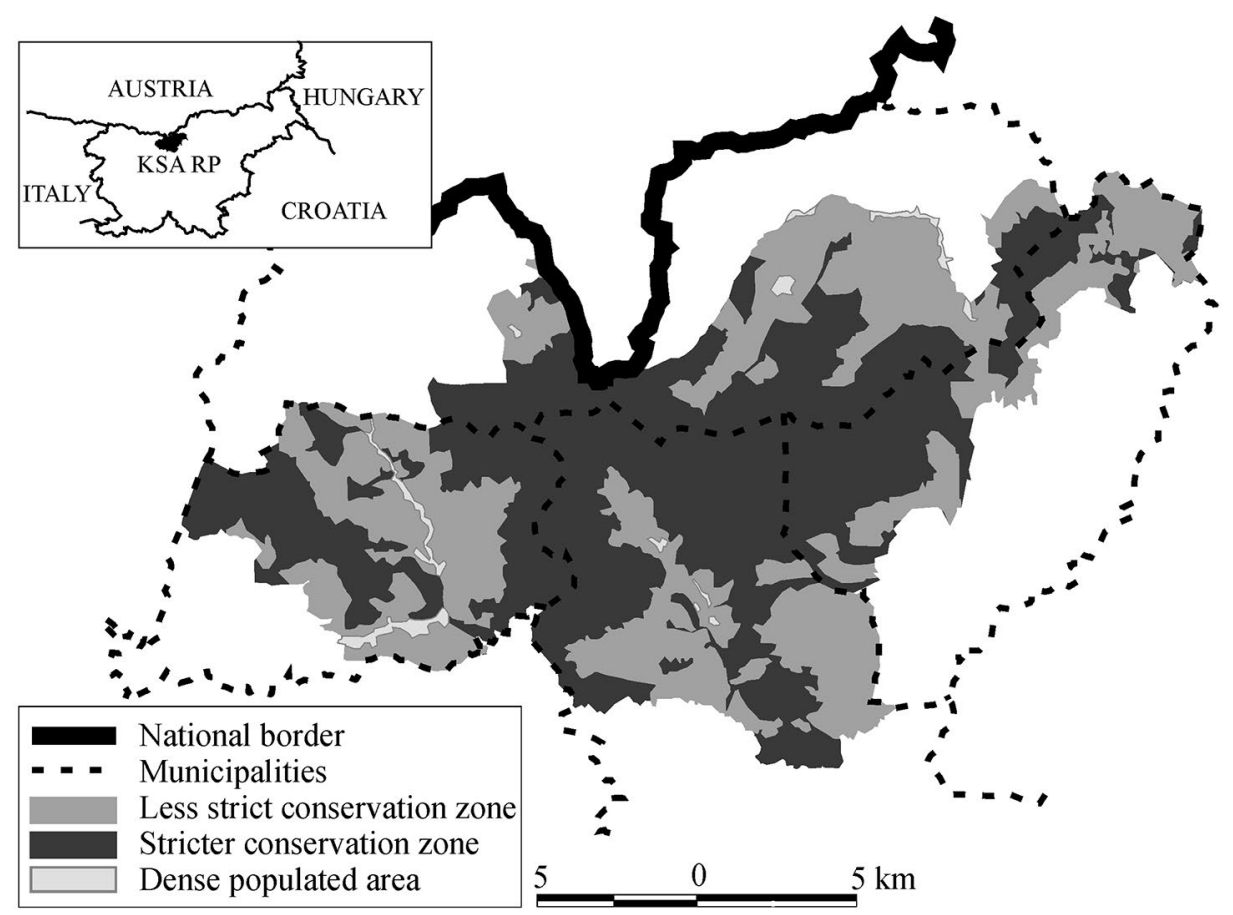

Figure 1. Location of the Kamniško-Savinjske Alps Regional Park in designation, Slovenia

Note. Boundaries of the park and conservation zones are still the subject of discussion.

Source: Image created by Mojca Nastran.

The PA is planned to encompass $264 \mathrm{~km}^{2}$. Due to its great significance to the European Union (EU), a large portion of this area is part of Natura 2000, an EUwide network of nature parks aimed at assuring the long-term survival of Europe's most valuable and endangered species and habitats (European Commission, 2015). The primary natural values of this area are birds species (e.g., Glaucidium passerinum and Tetrao urogallus), dwarf pines (Pinus mugo), the area above the tree line, and rare alpine animal and plant species. Smaller individual parts of the area have already been proclaimed as extensive PAs (Logarska Valley Nature Park, $24 \mathrm{~km}^{2}$, and Robanov kot, $14 \mathrm{~km}^{2}$ ). Approximately 650 people live in this area which includes 30 farms (Nastran, 2013). The park's objectives, as cited in the draft regulation, are conservation (the preservation of unspoiled nature, natural heritage, Natura 2000 sites, biodiversity, a favorable status of protected flora and fauna, landscape diversity, and sustainable use of natural resources) and development (the residents' quality of life and preserving population numbers by encouraging sustainable development consistent with local tradition). Foreseeable advantages for the local community are mostly economic, social, and cultural (Niedziałkowski et al., 2014), such as tourist visibility, infrastructure improvement, and target project money intended for, for example, agriculture and forestry support, settlement preservation, social integration, and employment. 
In the draft regulation, development policies and measures are defined, as well as some prohibitions. Activities in the park that may worsen the hydrological, geomorphological, or ecological conditions in the park are not permitted, nor are activities which could worsen the status of endangered and internationally protected species and their habitats. Such activities include introducing alien species, intensive aquaculture, camping and parking outside designated areas, and releasing genetically modified organisms into the environment and using them. In the less strict conservation zone, it is not permitted to build holiday homes, to open a quarry, or to drive a vehicle except for the purpose of public service, intervention, agriculture, or forestry work. In the strict conservation zone, prohibited activities include creating new grazing areas, building new objects, creating new recreational areas, cycling, and horse riding off-road.

\section{Methods}

In order to get insight into the various factors and their extent in influencing the local population's perception toward the PA, a questionnaire was designed that included various topics such as the establishment process; stakeholders' involvement and their perceptions about it; attitudes toward nature conservation, PAs, and the park; and expected changes after the park's establishment.

\section{Questionnaire and data}

Through its opinion and perception of a park in designation, the local population contributes greatly to a park's founding and its later operation, which is why local inhabitants are recognized as key stakeholders (Nastran, 2013). Therefore, the total sample $(n=128$ households) includes inhabitants with permanent residence in the planned KSARP $(\mathrm{N}=67)$ and people living just outside the park boundary but in the founding municipalities $(\mathrm{N}=47)$. Every household within the park boundary was sent a questionnaire in the mail while people living outside the park boundary filled out an identical online questionnaire. Only one adult member of the household had to fill out the questionnaire. Data was collected from August to October 2011.

In the statistical analysis of the data, the dependent variable is the binary variable "opinion of the park." The independent variable group includes socioeconomic variables which are often applied to similar studies (municipality, place of residence, gender, education, age, size of land) and variables we recognized as potentially influencing perception (perceiving the park as having development potential, participation in the founding of the park until its standstill in 2010, wish for participation in park planning and management in the future) (Table 1). 
Table 1. Dependent and independent variables included in statistical analyses

\begin{tabular}{|c|c|c|c|c|}
\hline & Variable & Category & $F(n=128)$ & $\%$ \\
\hline \multirow[t]{3}{*}{1} & \multirow[t]{3}{*}{ Opinion of the park } & I support the park & 77 & 60.2 \\
\hline & & I oppose the park & 36 & 28.1 \\
\hline & & Missing values & 15 & 11.7 \\
\hline \multirow[t]{7}{*}{2} & \multirow[t]{7}{*}{ Municipality } & Solčava & 26 & 20.3 \\
\hline & & Kamnik & 48 & 37.5 \\
\hline & & Jezersko & 8 & 6.3 \\
\hline & & Luče & 2 & 1.6 \\
\hline & & Preddvor & 32 & 25.0 \\
\hline & & Other & 11 & 8.6 \\
\hline & & Missing values & 1 & 0.8 \\
\hline \multirow[t]{3}{*}{3} & \multirow[t]{3}{*}{ Place of residence } & Inside the park & 67 & 52.3 \\
\hline & & Outside the park & 47 & 36.7 \\
\hline & & Missing values & 14 & 10.9 \\
\hline \multirow[t]{3}{*}{4} & \multirow[t]{3}{*}{ Gender } & Female & 58 & 45.3 \\
\hline & & Male & 66 & 51.6 \\
\hline & & Missing values & 4 & 3.1 \\
\hline \multirow[t]{3}{*}{5} & \multirow[t]{3}{*}{ Education } & Secondary, vocational school or less & 66 & 51.6 \\
\hline & & College, university or more & 54 & 42.2 \\
\hline & & Missing values & 8 & 6.3 \\
\hline \multirow[t]{2}{*}{6} & \multirow[t]{2}{*}{ Age } & Ordinal variable & 114 & 89.0 \\
\hline & & Missing values & 14 & 10.9 \\
\hline \multirow[t]{2}{*}{7} & \multirow[t]{2}{*}{ Size of land } & Ordinal variable & 44 & 34.4 \\
\hline & & Missing values & 84 & 65.6 \\
\hline \multirow[t]{2}{*}{8} & \multirow{2}{*}{$\begin{array}{l}\text { Perceiving the park as having } \\
\text { development potential }\end{array}$} & Ordinal variable & 112 & 87.5 \\
\hline & & Missing values & 16 & 12.5 \\
\hline \multirow[t]{6}{*}{9} & \multirow{6}{*}{$\begin{array}{l}\text { First source of information on } \\
\text { the founding of the park }\end{array}$} & Media & 19 & 14.8 \\
\hline & & Public presentation & 17 & 13.3 \\
\hline & & Information from the founders themselves & 19 & 14.8 \\
\hline & & Friends and acquaintances & 21 & 16.4 \\
\hline & & Foresters & 3 & 2.3 \\
\hline & & Missing values & 49 & 38.3 \\
\hline \multirow[t]{3}{*}{10} & \multirow{3}{*}{$\begin{array}{l}\text { Participation in the founding of } \\
\text { the park until the standstill of } \\
\text { foundation in } 2010\end{array}$} & Active participation & 9 & 7.0 \\
\hline & & Passive participation & 70 & 54.7 \\
\hline & & Missing values & 49 & 38.3 \\
\hline \multirow[t]{3}{*}{11} & \multirow{3}{*}{$\begin{array}{l}\text { Wish for participation in park } \\
\text { planning and management in } \\
\text { the future }\end{array}$} & Active participation & 51 & 39.8 \\
\hline & & Passive participation & 63 & 49.2 \\
\hline & & Missing values & 14 & 10.9 \\
\hline \multirow[t]{2}{*}{12} & \multirow{2}{*}{$\begin{array}{l}\text { Satisfaction with the } \\
\text { cooperation }\end{array}$} & Interval variable (7-point Likert scale) & 77 & 60.2 \\
\hline & & Missing values & 51 & 39.8 \\
\hline
\end{tabular}


Who Is For or Against the Park? Factors Influencing the Public's Perception of a Regional Park

\begin{tabular}{|l|l|l|r|c|}
\hline & Variable & Category & $\mathbf{F}$ (n = 128) & \% \\
\hline 13 & Trust in the founders & Interval variable (7-point Likert scale) & 115 & 89.8 \\
\cline { 3 - 5 } & & Missing values & 13 & 10.2 \\
\hline \multirow{3}{*}{14} & \multirow{2}{*}{ Meaning of land in the park } & Solely as property & 20 & 15.6 \\
\cline { 3 - 5 } & & Main source of income & 8 & 6.3 \\
\cline { 3 - 5 } & $\begin{array}{l}\text { Additional source of income and source } \\
\text { of raw materials for private use }\end{array}$ & 16 & 12.5 \\
\cline { 3 - 5 } & Safety net for times of crisis & 0 & 0.0 \\
\cline { 3 - 5 } & Place for relaxation and leisure time & 9 & 7.0 \\
\cline { 3 - 5 } & Missing values & 75 & 58.6 \\
\hline
\end{tabular}

Notes.

1 In the statistical analysis of gained data, the dependent variable is the binary variable "opinion of the park," which was remodeled from a nominal variable with four categories in the following manner: the category "I support the park" combines the answers "I support the idea of the park" and "I support the park being founded with certain changes," whereas the category "I oppose the park" combines the answers "nature needs to be preserved, but not in the form of a regional park" and "I oppose any kind of nature protection in this area."

8 "Perceiving the park as having development potential" is the result of a factor analysis procedure. One of the two factors combines six variables which describe the local population's change of expectation toward the KSARP in designation, using a 7-point Likert scale (from 1 completely disagree to 7 strongly agree). The six variables were: people will start moving out of the park area, the park will limit agriculture and farm development, local infrastructure will improve, the park will result in increased tourist numbers and job vacancies in the tourist field, the park will turn into wilderness without human activity, the possibility for the development of crafts and businesses will improve.

Kaiser-Meyer-Olkin test and Bartlett's test were used to test factor reliability and characteristics. Both showed reliable results: KMO (0.729), Bartlett (chi-square 173.890, df 15, p < 0.000).

10 The variable "participation in the founding of the park until the standstill of foundation in 2010 " is based on eight nominal values gathered into two categories:

(a) Passive participation: "I was only notified about the park being founded or acquainted with the idea," "I made a suggestion to the municipality that a park should be founded in the KSA," "I participated in choosing the name and the logo for the regional park," "I participated in notifying locals about the park being founded," "I came to the public discussion of the regional park draft regulation."

(b) Active participation: "I helped the planners determine the park area (i.e., the borders)," "I took part in determining development guidelines and measures for the park," "I wrote down or spoke about my views on the park contents."

If the interviewee had actively participated in at least one activity, they were classified as having taken active participation in the founding of the park thus far.

11 The variable "wish for participation in park planning and management in the future" is formed based on 10 nominal values. It combines both the passive and active approach to future planning of the park and its operation:

(a) Passive: "I wouldn't wish to participate in park planning," "I would make a suggestion to the municipality or the state that a park should be founded in the KSA," "I would participate in choosing the name and the logo for the regional park," "I would come to the public discussion of the regional park draft regulation," "I would help aligning the park contents with the local population."

(b) Active: "I would help the planners determine the park area (i.e., the borders)," "I would take part in determining development guidelines and measures for the park," "I would help draft a management plan after the park has been founded," "I would take part in park management as a member of the management board and the park council, as well as the person implementing the measures," and "as a member of the supervisory board, I would participate in supervising park management and its management plan execution."

If the interviewee would take active participation in at least one of the abovementioned activities, it was regarded that the interviewee would take active participation in park planning and its operation. 


\section{Statistical analysis}

To determine what factors influence the local population's perception of the park, discriminant analysis was used. Its aim is to determine the variables or factors that best distinguish two or more groups. This information is provided through the discriminant function, a new variable whose interpretation needs to take into consideration the eigenvalue and canonical correlation, Wilks's lambda test, Box's $M$ test, and standardized canonical discriminant function coefficients. Box's M test is used to test the null hypothesis for homogeneity of covariance matrices between groups, which has to be taken into consideration in smaller samples. The eigenvalue indicates the proportion of variance explained, Wilks's lambda test is used to express discriminant function characteristics and determine the total share of unexplained variability. Standardized canonical discriminant function coefficients are used to express the relative importance of individual variables when distinguishing among groups and their prefixes determine the path of the variables' influence on group classification (Kastelec \& Košmelj, 2008). All statistical analyses were performed with the SPSS program.

In the first phase of the analysis, discriminant analysis was carried out separately, taking into consideration the variables for individual thematic groups: (1) population's conservation affinity, (2) population's inclusion in the founding process and population's trust in the founders, and (3) population's socioeconomic status. The aim was to determine which thematic group best defines the population's inclination for or against the park being founded. Since the models, taking into consideration the thematic groups, did not show any significant results, we excluded from each group the variables that showed the largest influence when classifying units within a group. Based on results from previous discriminant analyses, the following variables were excluded from further analysis: "perception of the park," "municipality," and "active participation in the founding of the park thus far." Due to covariance matrix inequality among the groups (Box's $M$ test), the variables "size of land" and "meaning of land in the park" were also excluded from further analysis.

The final discriminant analysis model (Table 2) includes nine variables which were previously determined as having weak correlation among each other $(\mathrm{R}<0.3)$. Since Box's M test result did not prove to be significant $(p=0.877)$, the results presented further on are reliable. Eigenvalue shows that the discriminant function explains $74.3 \%$ of the between-group variance. Since Wilks's lambda value is statistically significant $(p=0.000)$, we can claim an important difference between the two groups. With its regression coefficients, its estimated canonical correlation coefficient $(\mathrm{R}=0.74)$, group centroid distance, and the results of the predicted initial group classification $(88.1 \%)$, discriminant analysis is relatively good at distinguishing the groups' support of and opposition to the park being founded. 


\section{Results and discussion}

Results show that some of the stakeholders' characteristics can affect their support of or opposition to the planned park in a generalized way. Those supporting the park differed from those opposing it in the fact that they see development potential in the park, that they were informed about the plan to found the park by the founders, and that they trust them to lead the founding process in cooperation with all interest groups (Table 2).

Table 2. Factors forming the opinion for or against KSARP being founded: standardized canonical coefficients and other discriminant function tests

\begin{tabular}{|l|c|c|}
\hline & D1 & Sig. \\
\hline Perceiving the park as having development potential & 0.803 & 0.000 \\
\hline First source of information about the park was personal contact with the founder & 0.514 & 0.021 \\
\hline Trust in the founders & 0.485 & 0.002 \\
\hline Age & -0.484 & 0.102 \\
\hline Place of residence - inside the park & 0.228 & 0.255 \\
\hline Satisfaction with the cooperation & 0.134 & 0.157 \\
\hline Education - college, university or more & 0.121 & 0.014 \\
\hline Wish for participation in park planning and management in the future & 0.081 & 0.042 \\
\hline Gender - male & -0.039 & 0.480 \\
\hline Canonical correlation & 0.743 & \\
\hline Wilks's lambda - significance & 0.000 & \\
\hline Group centroids & & \\
\hline \multicolumn{1}{|c|}{ Support the park } & 0.752 & \\
\hline Oppose the park & -1.584 & \\
\hline Original grouped cases correctly classified (\%) & 88.1 & \\
\hline
\end{tabular}

The highest value of the regression coefficient (0.80) is expressed in the variable "the stakeholders perceive the park as having development potential." There is an important difference between the two groups in the way they were informed about the plans for the park and how much they trust the founders: "the first source of information about the park was personal contact with the founder" $(0.51)$ and "trust in the founders" (0.49). The influence on classification within a group is expressed through the variable "age" (-0.48), but this variable shows no statistically significant correlation with the dependent variable, along with the variables "place of residence," "gender," and "satisfaction with the cooperation." 


\section{Development potential}

The population's classification into the groups opposing or supporting the park is mostly influenced by them perceiving the park as having development potential. This means that they see some direct or indirect economic and lifestyle benefits such as improvement of local infrastructure, increased tourist numbers and job vacancies, agriculture and farm development, new possibilities for crafts and businesses, and preserved settlements.

Several studies have shown that a positive perception of a PA is influenced by reaping or perceiving benefits from the founded PA (e.g., Ezebilo \& Mattsson, 2010; Htun et al., 2012; Karanth \& Nepal, 2012; Macura et al., 2011; Niedziałkowski et al., 2014; Tomicevic et al., 2010; Vodouhê et al., 2010). Since KSARP has not yet been founded, the inhabitants reap no benefits from the park, but the support for the park is heavily influenced by the idea of the park having benefits for the area's development. Because the KSARP, as well as other PAs, has not only conservation but also development objectives, the local stakeholders should be encouraged to express their wishes and ideas in relation to local sustainable development. Managers should provide an environment that encourages stakeholders to participate in development projects (HirschnitzGarbers \& Stoll-Kleemann, 2011; Sirivongs \& Tsuchiya, 2012). This way, locals can be better integrated in PA management and can also receive some benefits.

The results clearly show that the development objective of the park is, along with nature conservation, very important. This is what could convince people to support the park. People who are satisfied with their environment and their situation in it are part of the social capital of the region and their social selfesteem increases. Park development also depends on trust among people and it is a necessary precondition to achieve positive results in biodiversity (Pretty \& Smith, 2004). This way, we can say that conservation and development are interlinked and interdependent.

\section{Information about the park and trust in the founders}

The way in which the park was presented to the local inhabitants was very important for them. This has an important connection with the first information that the population was given regarding the founding of the park. The higher the trust that the founders will lead the founding process in cooperation with all interest groups, the more support for the park. The population feels it is important for the founders to contact them personally and inform them personally about the status of the founding process. Niedziałkowski and colleagues $(2012,2014)$ recognize that the lack of clear information about managing led to diminished trust in the founders of the Białowieża National Park in Poland. In keeping with our results, Stern (2008) also notes that trust 
is one of the most consistent predictors of exercised restraint across PAs. Trust is a basic need for successful cooperation between local stakeholders and founders (Abbas et al., 2014; Schmidt et al., 2014). Low confidence in a park's founders (state and municipalities) is a result of past negative experiences with them, such as insufficient communication, top-down environmental decisions, lack of transparency, and land nationalization. Direct communication, local participation, and some good practices could appreciably improve trust. Contrary to our expectations, the population's active participation in the founding of the park until the standstill of foundation in 2010, its satisfaction with inclusion in the processes, and its wish for active participation in the future play no significant role in its classification as supporting or opposing the park. Previous studies give different results regarding participation. Hirschnitz-Garbers and Stoll-Kleemann (2011), Sirivongs and Tsuchiya (2012), and Toomey and Domroese (2013) record some positive effects on attitudes and perceptions, while Macura et al. (2011) and Niedziałkowski et al. (2012) show the negative consequences of participation. Our results show that the population's perception is much more influenced by the way they were informed about the park being founded than their active participation in the founding of the park or their wish to participate in the founding. The results of research among the local stakeholders in Slovenia (Nastran, 2013, 2015) also confirm that the local population wish to participate in the park activities but in a passive rather than an active way. One possible explanation could be the request of the local population for procedural justice (Gross, 2008; Kerselaers et al., 2013; Niedziałkowski et al., 2014), which is not so much about opposing the park as it is about their wish to be heard, informed, and respected as a stakeholder, and to have an opportunity to contribute to the results. This could also be easily connected with trust and sources of information. It does not refer just to the outcomes of the process but also to the process of designation itself; who and how do the founders inform about the park or invite to be part of the designation process. Gross (2007) reports that perceptions of fairness do influence how people perceive the legitimacy of the outcome in a case of wind energy in Australia. In our case, trust is a crucial factor which stakeholders consider to be of high priority. Direct information from the founders and a sense of fair cooperation in the designation process have an evident impact on a park's perception.

\section{Other influences}

Most of the population living within the park boundary $(55 \%)$ or outside $(75 \%)$ supports the founding of the park. Contrary to other studies (Bonaiuto et al., 2002; Shibia, 2010; Triguero-Mas et al., 2009; Vodouhê et al., 2010), living within or outside the park boundary has no significant influence on interviewees' perceptions of the park in designation. This phenomenon could be explained by the fact that the people in the main populated areas are closely connected 
and have similar experiences from the past, the park founder's consistent communication strategy in the founding process thus far, or that the population has not yet been divided into those living inside and outside the park boundary as the park has not been formally founded.

Support for the KSARP is not significantly connected with the population's age, which is in contrast to other studies' results which found older people less favorable to PAs (e.g., Shibia, 2010; Tomicevic et al., 2010). Gender had no significant influence on the park's perception, a similar finding to other studies (e.g., Burn et al., 2012; Carrus et al., 2005; Shibia, 2010). However, some studies have found that women have less positive perceptions of PAs than men (Allendorf \& Allendorf, 2013; Tomicevic et al., 2010). Contrary to most previous studies, higher education is not connected with support for the park in our case. Further studies are necessary to explain these discrepancies.

\section{Conclusion}

The aim of this study was to determine the factors that influence the support of or opposition to the founding of the KSARP and the extent to which they do so. In contrast to similar studies, our study was conducted when the park was still being founded, not after it had been founded. Results show that there is a greater chance of opposition in the inhabitants who do not see the park as having development potential and who were not informed about the founding of the park directly from the founders. The latter result is connected with the fact that the population opposing the park being founded is more likely to not trust the park founders.

A study of the characteristics that define stakeholders' perceptions of the park is particularly important in designing further cooperation of founders with local stakeholders and in the subsequent management of the park. An understanding of the factors influencing the stakeholders' position makes it easier to find partners in the establishment of PAs. The research reveals the most common opponents to the park and the reasons for their opposition. This knowledge can lead to more targeted and effective participation. The findings can also inform the best methods for stakeholder involvement, since different groups of stakeholders require different participatory methods. To sum up, understanding the factors that affect the perception of PAs contributes to more effective stakeholder involvement, which is accepted to be one of the most important influences on the successful management of PAs. 
Belief that the park will bring development is the most important factor for the local population. This confirms that the park's further development and management needs to be linked to projects that are compatible with nature conservation and lead to the sustainable development of the local community. The second focus is to work on creating a positive relationship between the founders (and managers later) and the local stakeholders. Managers will need to establish a relationship that will encourage locals to participate, and accept that the desires and needs of the population are an indisputable part of the park and the key to the success of sustainable development and nature conservation.

The results of this study can be a guideline in planning cooperation with stakeholders in other places, but one has to take into consideration the unique natural and social characteristics of a given area. Finally, the results leave space for further qualitative research and for a comparison examining the processes of founding other PAs.

\section{Acknowledgments}

This research was conducted independently, without contract or the support of the founders of KSARP in designation. The opinions and conclusions expressed herein are those of the authors and do not necessarily represent the views of the founders of KSARP or any other agency. We would like to thank the anonymous reviewers for their constructive comments on earlier versions of the paper.

\section{References}

Abbas, N. H., van der Molen, I., Nader, M. R., \& Lovett, J. C. (2014). Citizens' perceptions of trust relationships in the environmental management process in North Lebanon. Journal of Environmental Planning and Management, 1-19. doi: 10.1080/09640568.2014.935757

Allendorf, T. D. (2010). A framework for the park-people relationship: Insights from protected areas in Nepal and Myanmar. International Journal of Sustainable Development \& World Ecology, 17(5), 417-422.

Allendorf, T. D., \& Allendorf, K. (2013). Gender and attitudes toward protected areas in Myanmar. Society \& Natural Resources, 26(8), 962-976.

Allendorf, T. D., Smith, J. L. D., \& Anderson, D. H. (2007). Residents' perceptions of Royal Bardia National Park, Nepal. Landscape and Urban Planning, 82(1-2), 33-40. 
Alonso-Yañez, G., \& Davidsen, C. (2014). Conservation science policies versus scientific practice: Evidence from a Mexican biosphere reserve. Human Ecology Review, 20(2), 3-29.

Arnberger, A., Eder, R., Allex, B., Sterl, P., \& Burns, R. C. (2012). Relationships between national-park affinity and attitudes towards protected area management of visitors to the Gesaeuse National Park, Austria. Forest Policy and Economics, 19, 48-55.

Arnberger, A., \& Schoissengeier, R. (2012). The other side of the border: Austrian local residents' attitudes towards the neighbouring Czech Šumava National Park. Journal for Nature Conservation, 20(3), 135-143.

Bonaiuto, M., Carrus, G., Martorella, H., \& Bonnes, M. (2002). Local identity processes and environmental attitudes in land use changes: The case of natural protected areas. Journal of Economic Psychology, 23(5), 631-653.

Burn, S. M., Winter, P. L., Hori, B., \& Silver, N. C. (2012). Gender, ethnic identity, and environmental concern in Asian Americans and European Americans. Human Ecology Review, 19(2), 136.

Carrus, G., Bonaiuto, M., \& Bonnes, M. (2005). Environmental concern, regional identity, and support for protected areas in Italy. Environment and Behavior, 37(2), 237-257.

Conrad, C. C., \& Hilchey, K. G. (2011). A review of citizen science and communitybased environmental monitoring: Issues and opportunities. Environmental Monitoring and Assessment, 176(1-4), 273-291.

Erhatič Širnik, R. (2003). Public participation in the establishment of the Kočevsko - Kolpa regional park (Unpublished master's thesis). University of Ljubljana, Slovenia.

European Commission. (2015). Natura 2000 network. Retrieved from http://ec.europa.eu/environment/nature/natura2000/index_en.htm

Ezebilo, E. E., \& Mattsson, L. (2010). Socio-economic benefits of protected areas as perceived by local people around Cross River National Park, Nigeria. Forest Policy and Economics, 12(3), 189-193.

Fakin Bajec, J. (2009). Kraški regijski park - realnost ali utopija? Začetki nastajanja projekta in razmišljanja o njegovi nadaljnji usodi. Izvestje Raziskovalne postaje ZRC SAZU v Novi Gorici, 2009(6), 27-34.

Flints, R. W. (2010). Seeking resiliency in the development of sustainable communities. Human Ecology Review, 17(1), 44-57. 
Government of Republica Slovenia. (2006). Resolution on National Environmental Action Plan 2005-2012.

Grošelj, A. (2008). An evaluation of methodology in creating nature parks in Slovenia (Unpublished master's thesis). University of Ljubljana, Slovenia.

Gross, C. (2007). Community perspectives of wind energy in Australia: The application of a justice and community fairness framework to increase social acceptance. Energy Policy, 35(5), 2727-2736.

Gross, C. (2008). A measure of fairness: An investigative framework to explore perceptions of fairness and justice in a real-life social conflict. Human Ecology Review, 15(2), 130-140.

Hirschnitz-Garbers, M., \& Stoll-Kleemann, S. (2011). Opportunities and barriers in the implementation of protected area management: A qualitative metaanalysis of case studies from European protected areas. Geographical Journal, $177(4), 321-334$.

Htun, N. Z., Mizoue, N., \& Yoshida, S. (2012). Determinants of local people's perceptions and attitudes toward a protected area and its management: A case study from Popa Mountain Park, Central Myanmar. Society \& Natural Resources, 25(8), 743-758.

Hu, J., Ping, X., Cai, J., Li, Z., Li, C., \& Jiang, Z. (2010). Do local communities support the conservation of endangered Przewalski's gazelle? European Journal of Wildlife Research, 56(4), 551-560.

Karanth, K. K., \& Nepal, S. K. (2012). Local residents perception of benefits and losses from protected areas in India and Nepal. Environmental Management, 49(2), 372-386.

Kastelec, D., \& Košmelj, K. (2008). Discriminant analysis and classification: Theory and illustration. Acta Agriculturae Slovenica, 91.

Kerselaers, E., Rogge, E., Vanempten, E., Lauwers, L., \& Van Huylenbroeck, G. (2013). Changing land use in the countryside: Stakeholders' perception of the ongoing rural planning processes in Flanders. Land Use Policy, $32,197-206$.

Kideghesho, J. R., Røskaft, E., \& Kaltenborn, B. P. (2007). Factors influencing conservation attitudes of local people in western Serengeti, Tanzania. Biodiversity and Conservation, 16(7), 2213-2230. 
Kos, D. (2002). Načela komunikacijskega delovanja. In D. Kos \& M. Marega (Eds.), Aarhuška konvencija v Sloveniji (pp. 135-141). Ljubljana: Regionalni center za okolje za srednjo in vzhodno Evropo.

Lind, E. A., \& Tyler, T. R. (1988). The social psychology of procedural justice. New York: Plenum Press.

Macura, B., Zorondo-Rodríguez, F., Grau-Satorras, M., Demps, K., Laval, M., Garcia, C. A., \& Reyes-García, V. (2011). Local community attitudes toward forests outside protected areas in India: Impact of legal awareness, trust, and participation. Ecology and Society, 16(3), Art. 10.

Mehta, J. N., \& Heinen, J. T. (2001). Does community-based conservation shape favorable attitudes among locals? An empirical study from Nepal. Environmental Management, 28(2), 165-177.

Mikuš, T. (2006). The state and perspectives of landscape parks in Slovenia (Unpublished master's thesis). University of Ljubljana, Slovenia.

Nastran, M. (2013). Stakeholder analysis in a protected natural park: Case study from Slovenia. Journal of Environmental Planning and Management, 57(9), 1359-1380.

Nastran, M. (2015). Why does nobody ask us? Impacts on local perception of a protected area in designation, Slovenia. Land Use Policy, 46, 38-49.

Nastran, M., \& Pirnat, J. (2012). Stakeholder participation in planning of the protected natural areas: Slovenia. Sociologija i Prostor, 50(2(193)), 141-164. doi: $10.5673 /$ sip. 50.2 .1

Niedziałkowski, K., Blicharska, M., Mikusiński, G., \& Jędrzejewska, B. (2014). Why is it difficult to enlarge a protected area? Ecosystem services perspective on the conflict around the extension of the Białowieża National Park in Poland. Land Use Policy, 38, 314-329.

Niedziałkowski, K., Paavola, J., \& Jędrzejewska, B. (2012). Participation and protected areas governance: The impact of changing influence of local authorities on the conservation of the Białowieża Primeval Forest, Poland. Ecology and Society, 17(1), Art. 2.

Pretty, J., \& Smith, D. (2004). Social capital in biodiversity conservation and management. Conservation Biology, 18(3), 631-638.

Rodela, R. (2010). A bottom-up rural regeneration initiative: A social learning analytical perspective. Paper presented at the 9th European IFSA Symposium, Vienna. 
Schmidt, L., Gomes, C., Guerreiro, S., \& O'Riordan, T. (2014). Are we all on the same boat? The challenge of adaptation facing Portuguese coastal communities: Risk perception, trust-building and genuine participation. Land Use Policy, 38, 355-365.

Shibia, M. G. (2010). Determinants of attitudes and perceptions on resource use and management of Marsabit National Reserve, Kenya. Journal of Human Ecology, 30(1), 55-62.

Sirivongs, K., \& Tsuchiya, T. (2012). Relationship between local residents' perceptions, attitudes and participation towards national protected areas: A case study of Phou Khao Khouay National Protected Area, central Lao PDR. Forest Policy and Economics, 21, 92-100.

Stern, M. J. (2008). The power of trust: Toward a theory of local opposition to neighboring protected areas. Society and Natural Resources, 21(10), 859-875.

Stringer, L. C., \& Paavola, J. (2013). Participation in environmental conservation and protected area management in Romania: A review of three case studies. Environmental Conservation, 40(2), 138-146.

Swim, J. K., Zawadzki, S. J., Cundiff, J. L., \& Lord, B. (2014). Environmental identity and community support for the preservation of open space. Human Ecology Review, 20(2).

Tomicevic, J., Shannon, M. A., \& Milovanovic, M. (2010). Socio-economic impacts on the attitudes towards conservation of natural resources: Case study from Serbia. Forest Policy and Economics, 12(3), 157-162.

Toomey, A. H., \& Domroese, M. C. (2013). Can citizen science lead to positive conservation attitudes and behaviors? Human Ecology Review, 20(1).

Triguero-Mas, M., Olomí-Solà, M., Jha, N., Zorondo-Rodríguez, F., \& ReyesGarcía, V. (2009). Urban and rural perceptions of protected areas: A case study in Dandeli Wildlife Sanctuary, Western Ghats, India. Environmental Conservation, 36(3), 208-217.

Vodouhê, F. G., Coulibaly, O., Adégbidi, A., \& Sinsin, B. (2010). Community perception of biodiversity conservation within protected areas in Benin. Forest Policy and Economics, 12(7), 505-512. 
This text is taken from Human Ecology Review, Volume 21, Number 2, 2015, published 2015 by ANU Press, The Australian National University, Canberra, Australia. 